Available online at website :

http:/ / e-journal.adpgmiindonesia.com/index.php/jmie

JMIE: Journal of Madrasah Ibtidaiyah Education, 4(2), 2020, 217-233

\title{
PENERAPAN E-LEARNING UNTUK MENGEMBANGKAN KETERAMPILAN KOMUNIKASI DI ERA REVOLUSI INDUSTRI 4.0 PADA PERKULIAHAN IPA
}

\author{
Mufida Awalia Putri \\ Universitas Alma Ata Yogyakarta, Indonesia \\ Email: mufida.awalia@almaata.ac.id
}

Submit: 13 Mei 2020, Revisi: 8 Juli 2020, Approve: 13 Oktober 2020

\begin{abstract}
This research aims to reveal the result of the e-learning to developing the communication skill of industry 4.0 era of students after its use in the teaching of natural science. E-learning platform that had been used was Moodle. This study was qualitative research that consisted of three stages: (1) data reduction, (2) data display, and (3) conclusion drawing / verification. The tryout subjects in this study were 36 students of Pendidikan Guru Sekolah Dasar semester 2. The data were collected by using an observation sheet to knew the indicator of communication skill, documentation, and interview. The results obtained by learning eLearning can develop skills that must be possessed in the era of the industrial revolution 4.0. This can be seen from the communication skills of students in attending science classes. Students can articulate thoughts and ideas effectively using writing; use communication to inform something; can use e-learning media; and can communicate effectively in a variety of environments. The development of this era requires that humans have these skills to face the Industrial Revolution 4.0.
\end{abstract}

Keywords: e-learning, industry revolution 4.0, natural science learning

Pengutipan: Mufida Awalia Putri. (2020). Penerapan E-Learning untuk Mengembangkan Keterampilan Komunikasi di Era Revolusi Industri 4.0 Pada Perkuliahan IPA. JMIE: Journal of Madrasab Ibtidaiyah Education, 4(2), 2020, 217-233. jmie.v4i2.183.

Permalink/DOI: http://dx.doi.org/10.32934/jmie.v3i2.183 


\section{PENDAHULUAN}

Perubahan era menjadi era digital 4.0 mendorong seluruh negara untuk meningkatkan kualitas sumber daya manusianya. Hal ini sangat berpengaruh terhadap sektor pendidikan baik pada tingkat yang paling bawah dan tingkat tinggi seperti perguruan tinggi. Berbagai macam strategi digunakan untuk menghasilkan output yang dapat bersaing di era ini. Pembangunan yang berkelanjutan, Indonesia telah ikut menyepakati Document Sustainable Development Goals (SDGs) dengan salah satu fokus pada tujuan secara global peningkatan kualitas pendidikan. Implementasi kesepakatan tersebut telah dikeluarkan (Presiden Republik Indonesia, 2017) tentang Pelaksanaan Pencapaian Tujuan Pembangunan Berkelanjutan, antara lain dengan menetapkan tujuan global pendidikan yakni "Menjamin kualitas pendidikan yang inklusif dan merata serta meningkatkan kesempatan belajar sepanjang hayat untuk semua".

Keterampilan abad 21 penting untuk menyokong perkembangan keterampilan masyarakat guna mensejahterakan hidupnya di era digital 4.0. Salah satu keterampilan abad 21 yaitu kemampuan berkomunikasi. Untuk mencari kerja saat ini keterampilan berkomunikasi juga sangat penting karena keterampilan untuk berinteraksi dengan orang-orang dari beragam latar belakang. Abad 21 mengharuskan desain lingkungan belajar khusus yang memfasilitasi perolehan keterampilan yang ingin dikembangkan oleh sistem pendidikan pada siswa sebagai bagian dari persiapan siswa untuk menghadapi kehidupan nyata pada lingkungan yang dinamis, cepat berubah, dan tidak pasti (Nissim et al., 2016).

Saat ini, terjadi pandemi virus Covid 19 yang melanda hampir seluruh negara di dunia. Hal ini mengakibatkan terbatasnya pertemuan untuk tatap muka atau pembelajaran langsung palagi melakukan eksperimen menggunakan fasilitas kampus. Social distancing salah satu hal yang wajib diterapkan sehingga kebijakan kampus untuk menerapkan Study From Home (SFH) atau belajar dari rumah. Dosen dan staf perguruan tinggi juga menerapkan Work From Home (WFH) atau kerja dari rumah. Hal ini mengharuskan dosen dan mahasiswa melakukan pembelajaran via daring yang menggunakan leptop atau gawai masing-masing dan pulsa internet.

IPA merupakan hasil interpretasi tentang alam (natural world). IPA sebagai proses/metode penyelidikan (inquiry methods) meliputi cara berpikir, sikap, langkah-langkah untuk memperoleh produk-produk IPA atau ilmu pengetahuan ilmiah misalnya observasi, pengukuran, merumuskan masalah, menguji hipotesis, mengumpulkan data, bereksperimen, dan prediksi. Berdasarkan konteks tersebut IPA bukan sekedar cara melihat dan cara berpikir, melainkan 'science as a way of knowing', artinya IPA sebagai proses juga dapat berupa keingintahuan, kebiasaan berpikir, dan seperangkat prosedur (Trowbridge, W. L. \&. Bybee, 1990).

(Chiappetta, E. L. \& Koballa, 2010) menjelaskan:

Ilmu pengetahuan alam adalah ilmu yang mempelajari tentang alam untuk memahaminya dan membentuk badan pengetahuan yang terorganisir yang memiliki daya prediksi dan aplikasi dalam masyarakat. Empat tema literasi sains atau dimensi ilmu pengetahuan yang harus jelas dalam instruksi ilmu adalah: (1) ilmu sebagai cara 
berpikir; (2) ilmu sebagai cara menyelidiki; (3) ilmu sebagai tubuh pengetahuan; dan (4) ilmu pengetahuan dan interaksi dengan teknologi dan masyarakat.

Interpretasi IPA tak lepas dari keterampilan berkomunikasi. Mahasiswa diharuskan dapat menjelaskan informasi-informasi yang didapat dengan cara yang tepat dan prosedural. Informasi dapat diperoleh dari berbagai media atau melakukan eksperimen untuk menunjukkan teori yang didapatkannya. Keterampilan komunikasi sangat dibutuhkan saat ini (Benešová \& Tupa, 2017) kualifikasi dan keterampilan yang diperlukan untuk profil pekerjaan Teknologi Informasi. Semua peran pekerjaan TI ini akan membutuhkan pengetahuan tentang proses untuk pemrosesan data yang benar.

Materi yang dipelajari yaitu Pesawat Sederhana; Suhu dan Kalor; dan Wujud Zat dan Perubahannya. Materi-materi ini yaitu materi fisika yang pernah dipelajari sebelumnya pada jenjang sekolah dasar dan sekolah menengah pertama. Pesawat sederhana merupakan materi yang dekat dengan kehidupan kita yaitu terdapat banyak benda-benda di sekitar yang menerapkan prinsip ini sehingga materi ini mudah unruk dipahami. Selanjutnya materi Suhu dan Kalor; Wujud Zat dan Perubahannya. Submateri kalori pada makanan pada awalnya yang kemudian berpindah pada submateri kalor dan perubahan suhu. Materi ini sangat tepat jika dikembangkan untuk dipadukan dengan lebih banyak materi biologi dan kimia dengan tidak menghilangkan esensinya. Walaupun sebagaian besar materi pada semester ini merupakan materi fisika namun IPA tidak bisa dipisah karena sangat berkaitan dengan yang lainnya. Mengingat pembelajaran IPA di SD pembelajarannya tidak secara terpisah tetapi saling berhubungan dengan ilmu IPA lainnya dan ilmu selain IPA. Kalor tidak hanya terdapat pada tubuh manusia, hewan, dan tumbuhan tetapi juga pada benda tak hidup. (Fatonah, S. \& Prasetyo, 2014) juga menyatakan bahwa pembelajaran sains seharusnya memuat aktivitas belajar yang menghubungkan dan mendukung produk-produk sains dalam dunia peserta didik.

Platform seperti Moodle memiliki fungsi yang berbeda, yang juga dapat dilihat sebagai solusi e-learning sendiri: dengan obrolan, forum atau sistem penumpang, siswa atau pekerja dapat berkomunikasi secara sinkron atau dengan cara yang tidak sinkron. Pengujian yang dilakukan dinilai secara otomatis, yang membuat pengujian yang sering juga cocok untuk kelompok besar (Schuster et al., 2015).

E-learning merupakan dasar dan konsekuensi logis dari perkembangan teknologi informasi dan komunikasi (Fauzan \& Arifin, 2019). E-learning telah dilaksanakan oleh banyak perguruan tinggi sebelum adanya pandemi ini. Namun pelaksanaanya masih dipadukan dengan pembelajaran tatap muka. Jadi dalam satu semester taerdapat beberapa kali pertemuan secara daring dan beberapa pertemuan secara tatap muka. Adanya pandemi ini maka perkuliahan via daring menjadi jalan utama demi tercapainya proses dan tersampaikannya tujuan pembelajaran kepada mahasiswa. e-learning telah menjadi kebutuhan perguruan tinggi dan sedang ditempatkan di tempat pendidikan di seluruh dunia (Islam et al., 2015). Pembelajaran abad 21 
dapat pula terjadi pada lingkungan online virtual yang memungkinkan pembelajaran jarak jauh, atau dengan kata lain, pembelajaran yang tidak tergantung dengan waktu dan tempat. Lingkungan belajar di abad 21 dapat saja berupa sebuah sistem pendukung proses yang mengatur situasi agar anak dapat belajar optimal (Nissim et al., 2016).

Pada pelaksanaannya perkuliahan tidak lepas dari penerapan berbagai model pembelajaran walaupun dilaksanakan dengan e-learning. Namun pada penelitian ini ditekankan pada penggunaan e-learning bukan pada model pembelajaran. Peran e-learning sangat mempengaruhi keterampilan di era Revolusi 4.0, sesuai dengan penelitian yang dilakukan (Sadikin \& Hakim, 2019) media e-learning interaktif berbasis web ini mendapat predikat 80,74\% (baik) setelah diujicoba pada peserta didik. Sementara guru bidang studi memberikan skor 80,76\% (baik).

\section{KAJIAN TEORI}

\section{A. Teknologi Pembelajaran e-Learning}

E-Learning merupakan pembelajaran yang menggunakan internet atau via daring. eLearning merupakan pembelajaran jarak jauh yang memanfaatkan teknologi komputer dan jaringan internet. e-learning telah menjadi kebutuhan perguruan tinggi dan sedang ditempatkan di tempat pendidikan di seluruh dunia (Islam et al., 2015). Pembelajaran ini juga mendukung dalam Startegi Peningkatan Akses yaitu pada sumber daya pendidikan terbuka dan teknologi yang tidak diskriminatif (Kementerian Pendidikan dan Kebudayaan, 2017).

Pelaksanaan pembelajaran online pada tahap awal membutuhkan pembiasaan terlebih dahulu bagi sivitas akademik untuk membantu proses adaptasi. Guru dan siswa membutuhkan keterampilan teknis untuk menggunakan komputer dalam konteks pendidikan (Nissim et al., 2016). Bahkan seorang guru muda yang tampaknya kerap menggunakan teknologi digital dan merupakan pengguna Twitter, Facebook, dan pesan teks yang terampil, belum tentu mereka mahir dalam penggunaan teknologi di bidang pendidikan sehingga proses belajar terus menerus diperlukan (Schrum \& Levin, 2017).

Tantangan saat ini bagi para akademisi di lingkungan e-learning adalah memahami gaya belajar berbeda dari siswa yang berbeda untuk hasil belajar yang lebih baik (Islam et al., 2015), (Callagan, V., Grdner, M., Horan, B., Scott, J., Shen, L., \& Wang, 2008) menyatakan meskipun ada model dan teori yang diusulkan untuk menghadapi perbedaan pembelajaran individual dan budayadi lingkungan e-learning, ada urgensi yang lebih besar dari penyedia konten untuk merancang kursus dan materi yang mempertimbangkan perbedaan ini dan melibatkan khalayak yang beragam secara budaya.

Moodle is the brainchild of Martin Dongiamas, who designed the program while working on his Ph.D. at Curtin University of Technology, Perth, Australia. He developed it as a tool for his dissertation which was on a Socio-constructivist approach to learning. Thus Moodle originally excelled in features which supported this approach to education, in particular through its very user-friendly discussion forum layout .... that can create web pages based on user input and data-based information. 
Moodle adalah gagasan dari Martin Dougiamas, yang merancang program saat mengerjakan gelar Ph.D. Dia mengembangkannya sebagai alat untuk disertasinya yang menggunakan pendekatan sosial-konstruktivis untuk belajar. Dengan demikian Moodle awalnya unggul dalam fitur-fitur yang mendukung pendekatan pendidikan, khususnya melalui tata letak forum diskusi yang sangat user-friendly yang dapat membuat halaman web berdasarkan input pengguna dan informasi berbasis data (Robb, 2004).

Moodle dibangun dengan cara yang sangat modular. Fungsi-fungsi baru dapat dibuat dan diaktifkan hanya dengan mengaktifkan ke direktori situs tempat semua modul plug-in disimpan. Bahasa tambahan dapat ditambahkan dengan cara yang serupa. Ada aliran saran yang konstan di situs Moodle.org tentang cara mengubah kode untuk mematikan elemen tampilan tertentu atau menambahkan yang baru. Fungsi-fungsi baru dan penyesuaian dengan yang lama yang bernilai abadi sering menemukan jalan mereka ke versi Moodle masa depan (Robb, 2004). Lahirlah konsep konsep pembelajaran yang mencoba menggabungkan produk software intelligence tersebut dalam komponen hardware intelligencenya yang berkembang setelah Robert Heinich, Leslie,J Briggs dan Rita Rachey mengembangkan konsep teknologi pembelajaran (Amanullah, 2020).

Universitas Alma Ata menggunakan platform ini sebagai pembelajaran daring. Setiap dosen dan mahasiswa mempunyai akun masing-masing yang dibuatkan oleh Tim IT kampus. Dosen sebagai pemberi materi berhak menyampaikan materi dan menggunakan menu-menu yang ada di e-Learning. Mahasiswa dapat mengikuti kuliah daring di alamat http://elearning.almaata.ac.id/.

\section{B. Model Pembelajaran}

Pembelajaran tentunya tak lepas dengan model pembelajaran. Model pembelajaran adalah pembelajaran yang merujuk pada pendekatan pembelajaran, lingkungan pembelajaran, dan manajemen kelas yang akan digunakan (Arends \& Richard, 1997).

Proses pembelajaran pada satuan pendidikan diselenggarakan secara interaktif, inspiratif, menyenangkan, menantang, memotivasi peserta didik untuk berpartisipasi aktif serta memberikan ruang yang cukup bagi prakarsa, kreativitas dan kemandirian sesuai dengan bakat, minat dan perkembangan fisik serta psikologis peserta didik, (Presiden Republik Indonesia, 2005).

Student Teams-Achievement Divisions (STAD) atau nama lainnya Tim Siswa Kelompok Prestasi (Slavin, Robert, 1995) merupakan salah satu tipe Kooperatif learning. STAD memiliki langkah-langkah yang pertama membentuk kelompok yang anggotanya kurang lebih 4 orang secara heterogen (prestasi, jenis kelamin, suku, dll), guru menyajikan pelajaran, guru memberi tugas kepada kelompok untuk dikerjakan oleh anggota-anggota kelompok, guru memberi 
kuis/pertanyaan kepada seluruh peserta didik. Pada saat menjawab kuis tidak boleh saling membantu, memberi evaluasi, dan membuat simpulan bersama.

Model ini termasuk dalam kelompok model pengajaran sosial. Model sosial, menitikberatkan pada bagaimana manusia mempelajari tingkah laku sosial, dan bagaimana interaksi sosial tersebut dapat mempertinggi hasil capaian pembelajaran akademik. Peran utama pendidikan adalah untuk mempersiapkan warga negara yang akan mengembangkan tingkah laku demokratis yang terpadu, baik dalam tataran pribadi maupun sosial serta meningkatkan taraf kehidupan yang berbasis demokrasi sosial yang produktif (Joyce et al., 1996).

Penelitian yang dilakukan oleh (Kadarwati et al., 2018) yang menggunakan Model Student Team Achievement Division (STAD) dan e-Learning pada pelajaran matematika, memperoleh perbedaan antara kelas yang menggunakan model STAD dan yang tidak. Dua kelas yang menggunakan model STAD nilai reratanya 88,67 dan 74,54 sedangkan yang tidak menggunakan STAD reratanya 63,10. Contohnya Model Pembelajaran Kooperatif tipe lainnya, yaitu e-jigsaw learning. Teknik pembelajaran jigsaw telah banyak digunakan pada pembelajaran dan merupakan teknik pembelajaran kooperatif yang efektif sebab mendorong sikap dan minat positif, mengembangkan keterampilan antarpribadi, dan meningkatkan pemahaman konseptual (Tarhan \& Acar Sesen, 2012). Penelitian di tingkat perguruan tinggi yang dilakukan (Rahmawati, 2020) juga menghasilkan bahwa Model e-Jigsaw Learning dapat meningkatkan keterampilan abad 21 pada perkuliahan fisika.

\section{Revolusi Industri 4.0}

Berkenaan dengan industri ini bahwa proses yang ada dan bebrapa bagian tidak fleksibel dapat direvolusi oleh komputer berkinerja tinggi, internet yang kuat, produk cerdas dan mesin melalui pertukaran informasi aktif. Menurut Industri Platform 4.0 proses produksi di masa depan akan didesentralisasi, yang berarti pergeseran jauh dari pabrik yang saat ini masih dikendalikan secara terpusat (Sommer, 2015)

Dalam beberapa dekade terakhir, revolusi industri keempat telah muncul, yang dikenal sebagai Industri 4.0. Industry 4.0 mengambil penekanan pada teknologi digital dari beberapa dekade terakhir ke tingkat yang sama sekali baru dengan bantuan interkonektivitas melalui Internet (What is Industry 4.0 - the Industrial Internet of Things, 2019). Komponen industri 4.0 meliputi: pengaplikasian kecerdasan buatan atau artificial intelligence; IoT adalah singkatan dari Internet of Things, sebuah konsep yang merujuk pada koneksi antara objek fisik seperti sensor atau mesin dan Internet; IIo'T adalah singkatan dari Industrial Internet of Things, sebuah konsep yang mengacu pada koneksi antara manusia, data, dan mesin yang berkaitan dengan manufaktur; Big data: Big data mengacu pada set besar data terstruktur atau tidak terstruktur yang dapat dikompilasi, disimpan, diorganisir, dan dianalisis untuk mengungkapkan pola, tren, asosiasi, dan peluang; kecerdasan buatan adalah konsep yang merujuk pada kemampuan komputer untuk melakukan tugas dan membuat keputusan yang secara historis membutuhkan tingkat kecerdasan 
manusia; digitalisasi: digitalisasi mengacu pada proses mengumpulkan dan mengubah berbagai jenis informasi menjadi format digital; cloud computing mengacu pada praktik menggunakan server jarak jauh yang saling terhubung yang diselenggarakan di Internet untuk menyimpan, mengelola, dan memproses informasi; dan ekosistem: suatu ekosistem, dalam hal manufaktur, mengacu pada potensi keterhubungan seluruh operasi Anda — inventaris dan perencanaan, keuangan, hubungan pelanggan, manajemen rantai pasokan, dan pelaksanaan manufaktur.

Dengan menggunakan Internet of Things, Internet of Services dan Internet of People akan membuat koneksi: mesin-mesin, manusia-mesin atau manusia-manusia, dan pada saat yang sama sejumlah besar data akan diperoleh. Untuk alasan ini akan perlu untuk menganalisis data besar (Big Data) untuk dapat memprediksi kemungkinan kegagalan dan beradaptasi secara real time dengan kondisi yang berubah (Benešová \& Tupa, 2017).

Keterampilan abad 21 terdapat 6 keterampilan yang salah satunya yaitu keterampilan komunikasi. Komunikasi mengacu pada kemampuan untuk mengedepankan ide dan informasi dengan cara yang jelas dan bermakna. Komunikasi memiliki empat tujuan utama, yaitu untuk memberi informasi, menginstruksikan, memotivasi, dan membujuk pendengar, mempunyai beberapa indikator yaitu: bersih, ringkas, konkrit, koheren, benar, dan lengkap (The 6Cs Squared Version of Education in the 21st Century, 2015). Komunikasi dikatakan efektif jika dapat memenuhi kebutuhan seseorang. Kebutuhan itu dapat dicapai melalui dua cara yaitu dengan atau tanpa memperhatikan kebutuhan atau minat lainnya (Blandhol, 2012).

Dalam menghadapi revolusi industri 4.0 ini, maka sumber daya manusia harus cakap dalam berkomunikasi. Mengartikulasikan pemikiran, menggunakan internet, dan mengolah data sehingga dapat bersaing secara kompetitif. Communication skill (keterampilan berkomunikasi) adalah keterampilan yang peserta didik harus dapat menganalisis dan memproses sejumlah informasi yang jumlahnya sangat melimpah dalam kehidupan atau pekerjaan sehari-hari. Peserta didik harus mampu menilai sumber-sumber informasi yang kredibel dan bagaimana sumbersumber informasi ini dapat digunakan secara efektif. Adapun indikator keterampilan komunikasi sebagai berikut: mengartikulasikan pemikiran dan gagasan secara efektif menggunakan lisan, tulisan, dan nonverbal; menggunakan komunikasi untuk berbagai tujuan (mis. untuk menginformasikan, menginstruksikan, memotivasi, dan membujuk); menggunakan banyak media dan teknologi, dan tahu bagaimana menilai dampak dan dampaknya; dan berkomunikasi secara efektif dalam beragam lingkungan (termasuk multibahasa dan multikultural), (Association, 2014).

Keterampilan abad 21 ini diintegrasikan dalam kaitannya dengan Penguatan Pendidikan Karakter saat ini, seperti penelitian yang dilakukan oleh (Anugerahwati, 2019) yang mengimplementasikan dengan pelajaran Bahasa Inggris di SMP. Penelitian (Mery Noviyanti, 2011) keterampilan komunikasi mempengaruhi prestasi belajar dalam tutorial online, keterampilan komunikasi berpengaruh positif terhadap prestasi belajar sebesar $74,7 \%$. 
Komunikasi yang sebaiknya dimiliki mahasiswa antara lain mengartikulasikan pemikiran dan gagasan secara efektif menggunakan lisan, tulisan, dan nonverbal (namun karena keterbatasan media maka hanya berdiskusi melalui tulisan); menggunakan komunikasi untuk menginformasikan sesuatu; dapat menggunakan media e-learning; dan dapat berkomunikasi secara efektif dalam beragam lingkungan.

Pelaksanaan e-learning ini dipadukan dengan menggunakan model pembelajaran kooperatif learning tipe STAD. Model ini digunakan untuk membiasakan mahasiswa bekerja secara berkelompok dan menyampaikan hasil diskusinya dengan kelompok di forum. Namun, penggunaan model ini dimodifikasi karena dilakukan secara daring atau tidak dapat dilakukan secara tatap muka langsung. Modifikasi model ini tentunya tidak mengubah sintaks yang ada. Penggabungan antara model kooperatif learning dengan e-learning dapat dilakukan dengan langkah-langkah: mahasiswa membentuk kelompok yang anggotanya 5 orang secara heterogen (prestasi, jenis kelamin, suku, dll); dosen memberikan tugas kepada mahasiswa untuk bekerja secara kelompok dan mempresentasikan hasil diskusinya mengenai satu materi di e-learning; dosen bersama mahasiswa yang lain mendiskusikan materi yang dipresentasikan mahasiswa di e-learning; guru memberi kuis/pertanyaan kepada seluruh mahasiswa. Pada saat menjawab kuis tidak boleh saling membantu (bekerja secara individu) di e-learning; dosen dan mahasiswa mengevaluasi bersama di e-learning; dan dosen dan mahasiswa membuat simpulan bersama di e-learning. Penilaian dilakukan secara online karena lebih efektif, seperti penelitian (Hardianti et al., 2017), penilaian alternatif berbasis web (e-assessment) dapat memfasilitasi mahasiswa dan dosen dalam proses pengumpulan dan penilaian tugas.

\section{METODE PENELITIAN}

Jenis penelitian ini adalah penelitian kualitatif yang bersifat deskriptif. Menurut Sugiyono metode penelitian kualitatif adalah metode penelitian yang digunakan untuk meneliti pada kondisi obyek yang alamiah (Sugiyono, 2017). Metode penelitian kualitatif dilakukan secara intensif, peneliti ikut berpartisipasi lama di lapangan, mencatat secara hati-hati apa yang terjadi, melakukan analisis reflektif terhadap berbagai dokumen yang ditemukan di lapangan, dan membuat laporan penelitian secara mendetail (Sugiyono, 2017).

Metode ini dimaksudkan untuk mendeskripsikan dan mengetahui keterampilan berkomunikasi untuk menghadapi Revolusi Industri 4.0 yang berkembang selama perkuliahan. Indikator mahasiswa mempunyai keterampilan berkomunikasi apabila mahasiswa dapat melakukan, antara lain mengartikulasikan pemikiran dan gagasan secara efektif menggunakan tulisan; menggunakan komunikasi untuk menginformasikan sesuatu; dapat menggunakan media e-learning; dan dapat berkomunikasi secara efektif dalam beragam lingkungan.

Metode pengumpulan data dengan menggunakan dokumentasi untuk mendokumentasikan kegiatan pembelajaran yang tersimpan di e-learning. Selanjutnya 
menggunakan metode observasi dan wawancara. Observasi dilakukan oleh peneliti sendiri dengan menggunakan instrumen lembar observasi yang disusun berdasarkan indikator-indikator keterampilan komunikasi dan divalidasi oleh ahli yaitu salah satu dosen evaluasi pembelajaran. Terdapat empat indikator pada lembar observasi diisi dengan mencentang pada kolom skor 1, 2, 3, dan 4. Skor 1 menunjukkan mahasiswa tidak aktif, skor 2 kurang aktif, 3 aktif, dan 4 sangat aktif. Metode yang terakhir yaitu wawancara dengan menggunakan pedoman wawancara yang digunakan untuk menggali kritik dan saran mahasiswa selama pembelajaran dan mengungkap respon mahasiswa. Panduan wawancara disusun berdasarkan indikator keterampilan komunikasi. Ketiga metode digunakan untuk triangulasi data. Menyamakan persepsi antara observer dan subjek penelitian.

Populasi penelitian ini adalah mahasiswa PGSD semester 2 Tahun Ajaran 2019/2020 sebanyak 47 mahasiswa pada mata kuliah Konsep IPA Dasar 2 yang menggunakan e-learning selama 3 pertemuan. Sebanyak tiga kali pertemuan ada 11 mahasiswa yang tidak mengikuti elearning secara terus menerus sehingga subjek penelitian menjadi 36 mahasiswa.

Pelaksanaan e-learning menggunakan alamat e-learning kampus yaitu http://elearning.almaata.ac.id/. Perkuliahan dimulai dengan mengatur aturan yang ada di dalam e-Learning. Menggunakan menu forum untuk berdiskusi. Dalam hal ini, mahasiswa akan dianggap hadir apabila dia bertanya dan menjawab pertanyaan yang diberikan oleh dosen ataupun mahasiswa. terlebih dahulu mahasiswa mempresentasikan materinya dan diikuti dengan diskusi dan pemecahan masalah. Setiap mahasiswa berhak mengungkapkan opininya berdasarkan dasar teorinya denga gaya tulisan masing-masing. Perkuliahan ini sesuai dengan sintaks Model STAD.

Aktivitas dalam analisis data yaitu data reduction, data display, dan conclusion drawing/verification. (Sugiyono, 2017). Data reduction (Reduksi data) Mereduksi data berarti merangkum, memilih hal-hal yang pokok, memfokuskan pada hal-hal yang penting, dicari temanya dan membuang yang tidak perlu. Dengan demikian data yang telah direduksi akan memberikan gambaran yang lebih jelas, dan mempermudah peneliti untuk melakukan pengumpulan data selanjutnya, dan mencarinya bila diperlukan. Pada penelitian ini akan direduksi data mengenai kehadiran mahasiswa. Subjek penelitian ditetapkan dengan kehadiran mahasiswa berturut-turut yaitu sebanyak tiga kali pertemuan karena observasi dilakukan setiap pertemuan. Total keseluruhan mahasiswa 47 mahasiswa tetapi ada yang tidak mengikuti di salah satu pertemuan maka tidak diikutkan sebagai subjek, sehingga subjek penelitian menjadi 36 .

Data display (Penyajian Data) Penyajian data adalah tahap lanjutan dari reduksi data. Dengan menyajikan data, maka akan memudahkan untuk memahami apa yang terjadi dan merencanakan kerja selanjutnya berdasarkan apa yang telah difahami tersebut. Subjek 36 mahasiswa digunakan datanya dari observasi, dokumentasi, dan wawancara. 
Conclusion Drawing / Verification (Penarikan Kesimpulan) Penarikan kesimpulan atau verifikasi merupakan tahap paling akhir dalam analisa data yang dilakukan dengan melihat hasil reduksi data dan tetap mengacu pada rumusan masalah serta tujuan yang hendak dicapai. Pada penarikan kesimpuan, peneliti dari awal mengumpulkan data dan mencari arti data yang telah dikumpulkan, setelah data disajikan penelitian dapat memberikan makna, tafsiran, argumen, membandingkan data dan mencari hubungan antara satu komponen dengan komponen yang lain sehingga dapat ditarik kesimpulan. Data yang telah tersusun kemudian dihubungkan dan dibandingkan antara satu dengan yang lainnya sehingga mudah ditarik kesimpulan sebagai jawaban dari permasalahan yang ada.

\section{HASIL DAN PEMBAHASAN}

Pengamatan menggunakan lembar observasi diperoleh data yang telah reduksi yaitu sebanyak 36 subjek. Setiap indikator dirata-rata pada setiap pertemuan yaitu ke-1, ke-2, dan ke3. Hasil dari pengamatan disajikan pata Tabel 1. Indikator lembar observasi juga digunakan dalam penyusunan panduan wawancara.

Tabel 1. Hasil Observasi Keterampilan Komunikasi

\begin{tabular}{llcccc}
\hline $\mathbf{N o}$ & Indikator & ke-1 & ke-2 & ke-3 & Rerata \\
\hline $\mathbf{1}$ & $\begin{array}{l}\text { mengartikulasikan pemikiran dan gagasan secara } \\
\text { efektif menggunakan tulisan; }\end{array}$ & 2,58 & 3,06 & 3,33 & 3 \\
\hline $\mathbf{2}$ & $\begin{array}{l}\text { menggunakan komunikasi untuk } \\
\text { menginformasikan sesuatu; }\end{array}$ & 2 & 3 & 3,33 & 2,78 \\
$\mathbf{3}$ & dapat menggunakan media e-learning; dan & 3 & 4 & 4 & 3,67 \\
$\mathbf{4}$ & $\begin{array}{l}\text { dapat berkomunikasi secara efektif dalam beragam } \\
\text { lingkungan. }\end{array}$ & 2,30 & 3,17 & 4 & 3,16 \\
& & 2,47 & 3,30 & 3,67 & 3,15
\end{tabular}

rerata per pertemuan

Mahasiswa mendapatkan bekal dalam menggunakan e-learning, seiring dengan berjalannya waktu dan kebiasaan dalam perkuliahan menggunakan e-learning, maka mereka semakin mahir dalam menggunakan beberapa menu dalam e-learning. Seperti masuk sendiri tanpa diundang keperkuliahan dengan cara memasukkan password yang sudah diberi tahu dosen. Mengunggah materi presentasi di forum, menanggapi di kolom komentar, menjawab kuis di fitur kuis, mengunggah file di kolom tugas, dan membuat forum di menu diskusi. Hal ini sesuai dengan hasil observasi pada poin ketiga yang menunjukkan kenaikan skor dari pertemuan pertama ke kedua. 
Mahasiswa juga semakin mahir dalam menyampaikan gagasannya dan tidak malu untuk menuliskannya di kolom komentar (indikator poin 1). Mereka semakin aktif dalam pembelajaran baik dalam bertanya dan menjawab pertanyaan. Walaupun ada mahasiswa yang meng-copy paste dari internet seperti yang dikonfirmasikan lewat wawancara. Namun, ada beberapa mahasiswa menjawab dengan menggunakan pengetahuan terdahulunya dan berfikir dari analoginya untuk memecahkan masalah yang tidak bisa dicari di internet. Hal ini sepadan dengan yang diungkapkan oleh (Schuster et al., 2015) pada dasarnya siswa dapat memperoleh informasi apa pun yang mereka inginkan dari internet, tetapi juga dapat berkontribusi aktif dalam forum, wiki, atau blog. Potensi ada di sana untuk mengubah peran siswa dari pengguna informasi yang agak pasif menjadi pencipta pengetahuan dalam struktur jaringan - dengan semua kelebihan dan kekurangan yang menyertainya. Dengan tujuan dalam pikiran tidak hanya untuk meningkatkan pengetahuan siswa dan untuk mendukung mereka untuk memperkuat kepribadian mereka selama bertahun-tahun, tetapi juga untuk mengembangkan kompetensi penting bagi dunia kerja mereka akan melangkah dalam berbagai jenis kolaborasi yang harus dilatih dan diuji dalam skenario pembelajaran.

Hasil keterampilan komunikasi yang diperoleh dari lembar observasi menunjukkan peningkatan dari pertemuan ke pertemuan. Terdapat mahasiswa yang mendapatkan hasil yang maksimal yaitu skor 4 pada semua aspek keterampilan komunikasinya sangat baik.

\section{Keterampilan Komunikasi}

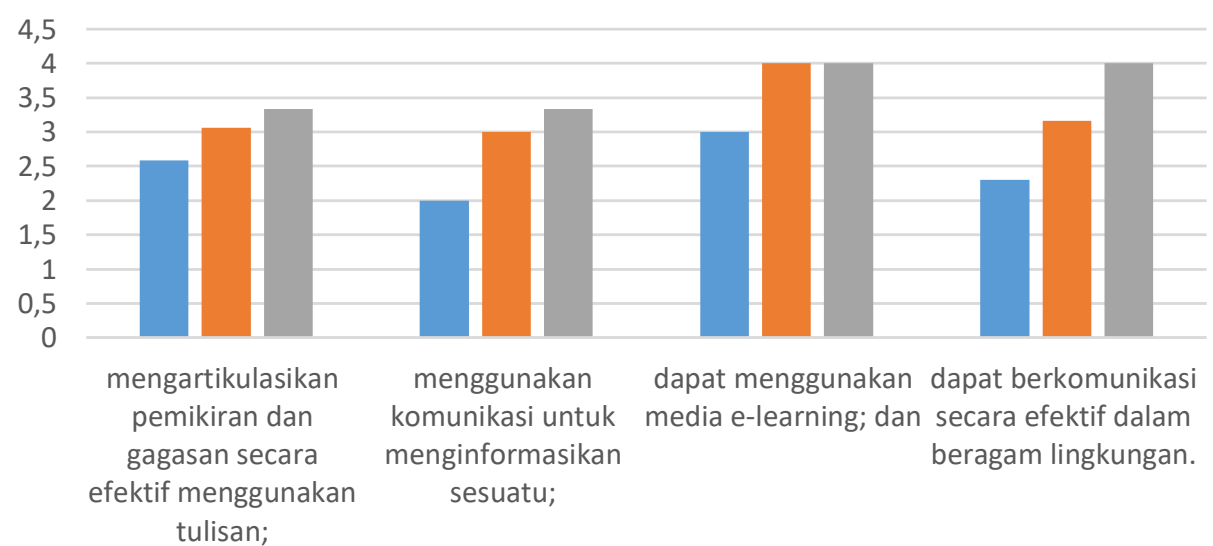

a ke-1 ke-2 a ke-3

\section{Grafik 1. Hasil Observasi Keterampilan Komunikasi}

Pertemuan pertama dengan materi Pesawat Sederhana dilaksanakan pada minggu pertama Study From Home (SFH). Mahasiswa membentuk kelompok yang anggotanya 5 orang secara heterogen (prestasi, jenis kelamin, suku, dll), pembentukan kelompok sudah dilakukan 
Mufida Awalia Putri

di awal semester sehingga pada saat jadwal perkuliahan mereka melanjutkan giliran presentasinya; kelompok yang presentasi mengerjakan tugas yang diberikan dosen yaitu membuat makalah dan materi untuk presentasi dengan mendiskusikannya dengan kelompoknya

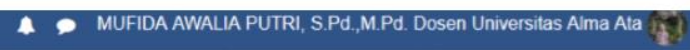

Re: Presentasi

by Amrulloh PENDIDIKAN GURU SD 2019 - Wednesday, 18 March 2020, 1:39 PM

Pesawat sederhana memiliki pengertian sebagai sebuah alat mekanik yang mampu merubah arah atau besaran yang timbul dari sebuah gaya. Secara umum, keberadaan pesawat sederhana ini bisa disebut sebagai sebuah sistem mekanis paling sederhana dengan memanfaatkan keuntungan mekanik guna meningkatkan gaya

Sebuah pesawat sederana akan memanfaatkan sebuah gaya kerja untuk dimanfaatkan melawan sebuah gaya beban, yang dapat mempermudah kita dalam melakukan suatuusaha. Tanpa memperhatikan sebuah gaya gesek yang muncul, maka kerja yang ditimbulkan oleh sebuah beban, akan memiliki besaran yang sama dengan kerja yang terjadi pada sebuah beban

PERMALINK SHOW PARENT EDIT SPUT DELETE REPLY

dan kemudian mempresentasikan di forum e-learning.

\section{Gambar 1. Presentasi di e-Learning}

Dalam menyampaikan materi mahasiswa harus menggunakan bahasa yang baik dan benar agar dapat tersampaikan pada mahasiswa lainnya. Setiap materi, presentator juga menggunakan bahasa yang komunikatif yaitu mengkonfirmasi kepada mahasiswa lainnya. Selanjutnya dosen mengkonfirmasi presentasi mahasiswa kemudian bersama mahasiswa yang lain mendiskusikan materi yang dipresentasikan mahasiswa di e-learning, yaitu dengan cara

Re: Presentasi

by Amrulloh PENDIDIKAN GURU SD 2019 - Wednesday, 18 March 2020, 1.55 PM

1. Pengungkit

Adalah suatu batang yang dapat berputar pada titik tumpu. Pengungkit dibedakan menjadi 3 berdasarkan letak titik tumpu(T), beban (B), dan kuasanya (K).

Untuk memudahkan kita dalam melakukan pekerjaan berat, contoh membuka tutup botol.

2. Katrol

adalah roda yang berputar pada poros dan biasa digunakan bersama-sama dengan rantai atau tali.

Untuk membantu kita mengangkat beban berat .

Contoh ketika kita menimba air di sumur.

Apakah sudah paham?

mahasiswa menanyakan materi yang belum jelas dengan bahasa yang mudah dimengerti dan dengan tata krama menanggapi yang baik. Begitu pula dengan mahasiswa yang tidak sedang presentasi tetapi ingin menjawab pertanyaan mahasiswa yang lain.

\section{Gambar 2. Memberikan pertanyaan}




\section{Gambar 3. Menjawab pertanyaan}

Di akhir pertemuan dosen memberi kuis/pertanyaan kepada seluruh mahasiswa. Hal ini mengetahui bahwa pesan yang disampaikan pada kuliah tersebut telah sampai secara merata (ke seluruh mahasiswa) atau hanya kepada beberapa mahasiswa saja. Pada pertemuan pesawat sederhana belum semua mahasiswa aktif dalam menanggapi di kolom komentar sehingga evaluasi harus dilakukan. Dengan ini mahasiswa menjawab pertanyaan secara individu. Teknik kuis menggunakan menu yang berbeda agar mahasiswa dapat menggunakan menu-menu yang ada di e-learning sehingga indikator keterampilan komunikasi poin ke-3 (dapat menggunakan media e-learning) meningkat.

Kemudian dosen mengkonfirmasi jawaban mahasiswa dan membahasnya bersama. Dosen dan mahasiswa membuat simpulan bersama di e-learning. Sebelum menutup kuliah, dosen mengingatkan untuk mempersiapkan materi berikutnya yaitu Suhu dan Kalor.

Pada pertemuan kedua, mahasiswa semakin meningkatkan keaktifannya dalam perkuliahan e-learning. Hal ini dibuktikan dengan, dapat mengartikulasikan pemikiran dan gagasan secara efektif menggunakan tulisan. Mahasiswa semakin aktif bertanya dan menjawab pertanyaan walaupun lewat tulisan. Lalu, menggunakan komunikasi untuk menginformasikan sesuatu.

Re: presentasi

Re: presentasi
by SELFI MARSELINA WIDIYASTUTI PENDIDIKAN GURU SD 2019 - Wednesday, 25 March 2020, 2:00 PM

izin menjawab pertanyaan dari mbk mifta, maaf jika salah dalam menjawab hehehe

1. Kalor dan Perubahan Suhu Benda

Air jika diberi panas dari pembakaran spirtus yang menyala, secara umum suhu benda yang dipanaskan akan naik jika benda itu mendapatkan kalor. sebaliknya suatu benda suhunya akan menurun jika benda tersebut melepaskan kalornya. air yang semula dididinkan lama kelamaan akan mendingin mendekat suhu ruang setelah air tersebut melepas kalornya. Hal ini menunjukkan bahwa sebagaian kalor dilepaskan benda tersebut kelingkungan. 2. kalor pada perubahan wujud benda

Terjadinya perubahan wujud sering diamati dalam kehidupan sehari-hari, contoh yang sering kita jumpai yaitu air yang mendidih kelihatan mengeluarkan gelembung-gelembung uap air yang menunjukkan adanya perubahan wujud dari air menjadi uap. untuk mendidihkan air diperluka kalor (panas), jadi untuk mengubah wujud zat cair menjadi gas diperlukan kalor. 


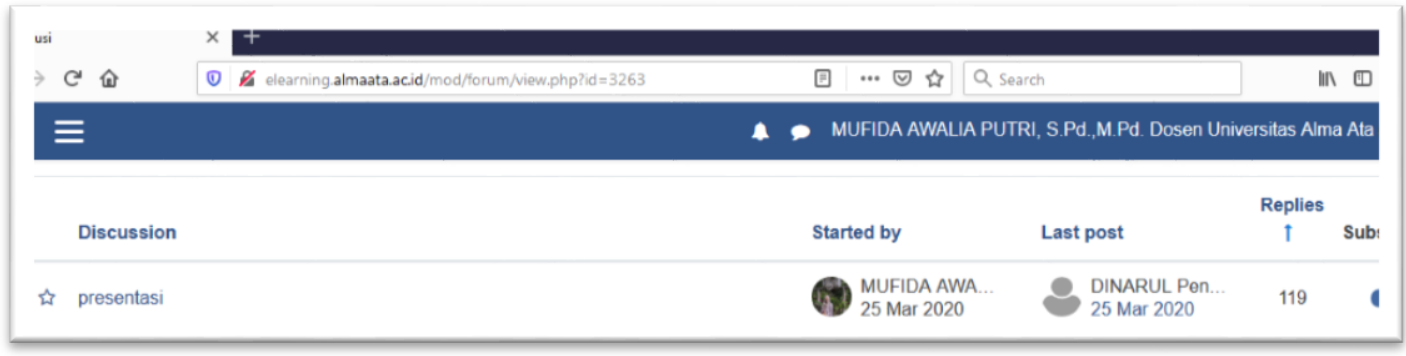

\section{Gambar 5. Pertemua Kedua 119 Replies}

Di pertemuan ketiga materi Wujud Zat dan Perubahannya, antusias mahasiswa meningkat. Hal ini dikarenakan kebiasaan dalam mengetik di e-learning sehingga mahasiswa tidak sungkan untuk mengikuti perkuliahan daring. Bahasa dalam menyampaikan juga sudah terlihat rapi dan efektif.

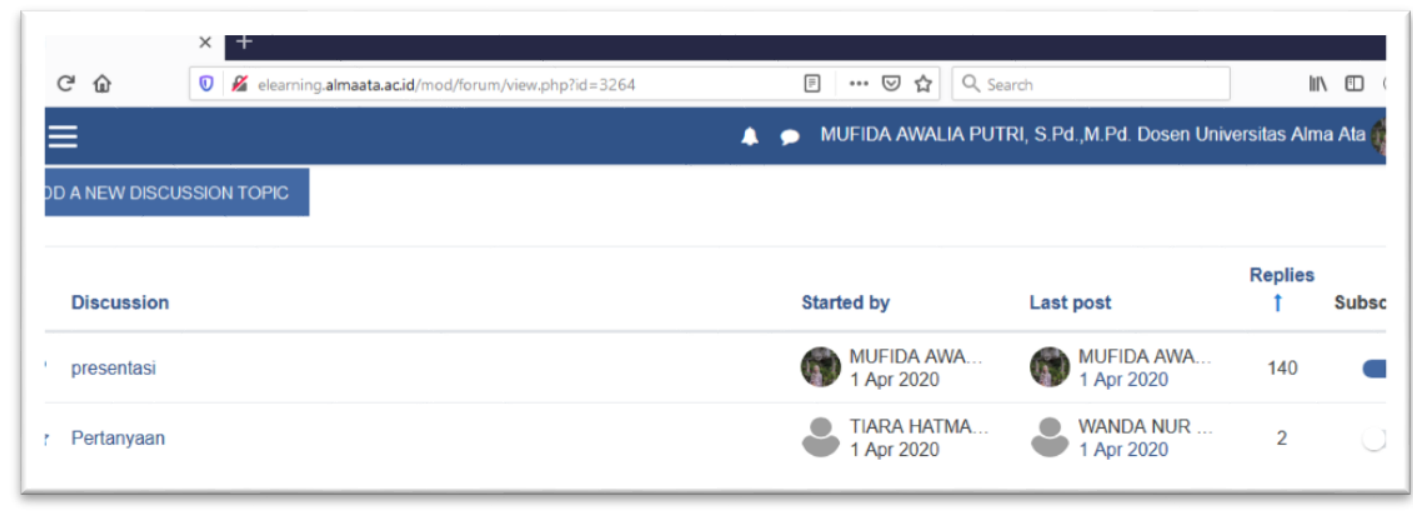

\section{Gambar 6. Antusias Mahasiswa 140 Replies}

Pada saat perkuliahan di kelas, beberapa mahasiswa tidak berani berkomentar atau mengungkapkan pendapatnya. Karena di dalam kelas terdapat mahsiswa dari lingkungan yang beragam. Maksudnya, ada yang cerewet, pendiam, pemalu, dan percaya diri. Tidak hanya itu, perbedaan watak bawaan dari ras/suku. Namun, di e-Learning mereka bebas mengetik pendapatnya di kolom komentar baik bertanya ataupun menjawab pertanyaan. Terdapat beberapa mahasiswa yang apabila di kelas tidak berani mengungkapkan pendapat/bertanya, tetapi di e-learning mereka sangat aktif dan mempunyai banyak opini untuk disampaikan. Kemampuan membaca mereka juga meningkat karena diharuskan untuk membaca. Kemampuan inilah yang diperlukan untuk menghadapi Revolusi Industri 4.0.

Pembelajaran e-learning dengan model Kooperatif Learning Tipe STAD ini dapat mendorong mahasiswa untuk melakukan diskusi. Pada saat menyusun makalah mahasiswa berdiskusi dengan teman sekelompoknya dan kemudian mempresentasikan dengan teman 
sekelas di e-learning. Hal ini dapat mengembangkan kemampuan komunikasinya. Melalui elearning, mahasiswa membaca makalah dan power point yang dibuat dan disajikan sesuai dengan gilirannya kemudian mereka dapat bertanya apabila ada materi yang belum dimengerti dengan cara me-replay. Selanjutnya mahasiswa yang dapat menjawab pertanyaan mahasiswa atau dosen juga dapat me-replay di kolom diskusi. Selain dapat belajar dari ilmu perkuliahan mereka juga mampu menerapkan ilmu komputernya yaitu penggunaan internet dan menggunakan menumenu di dalam e-learning. Perkembangan zaman ini mengharuskan manusia mempunyai keterampilan tersebut untuk menghadapi Revolusi Industri 4.0 sekaligus mendukung program pemerintah dalam mencapai generasi emas 2045.

\section{SIMPULAN}

Berdasarkan pembahasan tersebut dapat disimpulkan bahwa pembelajaran e-Learning dapat mengembangkan keterampilan yang harus dimiliki di era revolusi industri 4.0 ini. Hal ini terlihat dari keterampilan komunikasi mahasiswa dalam mengikuti perkuliahan IPA. Hal ini dibuktikan dengan, mahasiswa mengartikulasikan pemikiran dan gagasan secara efektif menggunakan tulisan; menggunakan komunikasi untuk menginformasikan sesuatu; dapat menggunakan media e-learning; dan dapat berkomunikasi secara efektif dalam beragam lingkungan. Perkembangan zaman ini mengharuskan manusia mempunyai keterampilan tersebut untuk menghadapi Revolusi Industri 4.0.

\section{DAFTAR PUSTAKA}

Amanullah, M. A. (2020). PENGEMBANGAN MEDIA PEMBELAJARAN FLIPBOOK DIGITAL GUNA MENUNJANG PROSES PEMBELAJARAN DI ERA REVOLUSI INDUSTRI 4.0. Jurnal Dimensi Pendidikan Dan Pembelajaran. https:// doi.org/10.24269/dpp.v0i0.2300

Anugerahwati, M. (2019). Integrating the 6Cs of the 21st Century Education into the English Lesson and the School Literacy Movement in Secondary Schools. KnE Social Sciences. https:// doi.org/10.18502/kss.v3i10.3898

Arends \& Richard, I. (1997). Classroom instruction and management. McGraw-Hill.

Association, N. E. (2014). Preparing 21st Century Students for a Global Society. An Educator's Guide to the "Four Cs."

Benešová, A., \& Tupa, J. (2017). Requirements for Education and Qualification of People in Industry 4.0. Procedia Manufacturing. https:// doi.org/10.1016/j.promfg.2017.07.366

Blandhol, S. (2012). Blandhol, S. (2012). Teaching Interpersonal Communica-tion Skills Using an Internet Based Intervention: a Randomised Controlled Trial.Thesis Master.

Callagan, V., Grdner, M., Horan, B., Scott, J., Shen, L., \& Wang, M. (2008). A Mixed Reality Teaching and Learning Environment. International Conference on Hybrid Learning and Education.

Chiappetta, E. L. \& Koballa, T. R. (2010). Science Instruction in the Middle and Secondary Schools: Developing Fundamental Knowledge and Skills (7th ed.). Pearson. 
What is Industry 4.0 - the Industrial Internet of Things, (2019).

Fatonah, S. \& Prasetyo, Z. K. (2014). Pembelajaran sains. Penerbit Ombak.

Fauzan, F., \& Arifin, F. (2019). The Effectiveness of Google Classroom Media on the Students' Learning Outcomes of Madrasah Ibtidaiyah Teacher Education Department. Al Ibtida: Jurnal Pendidikean Guru MI, 6(2), 271.

https://doi.org/10.24235/al.ibtida.snj.v6i2.5149

Hardianti, R. D., Taufiq, M., \& Pamelasari, S. D. (2017). The development of alternative assessment instrument in web - based scientific communication skill in science education seminar course. Jurnal Pendidikan IP A Indonesia. https:/ / doi.org/10.15294/jpii.v6i1.7885

Islam, N., Beer, M., \& Slack, F. (2015). E-Learning Challenges Faced by Academics in Higher Education: A Literature Review. Journal of Education and Training Studies. https:// doi.org/10.11114/jets.v3i5.947

Joyce, B. R., Weil, M., \& Calhoun, E. (1996). Models of Teaching, 5th Edition. In Models of teaching.

Kadarwati, S., Astutik, K., \& Prayitno, E. (2018). KEEFEKTIFAN MODEL STUDENT TEAM ACHIEVEMENT DIVISION (STAD) DAN E-LEARNING PADA MATERI OPERASI PENJUMLAHAN DAN PENGURANGAN PECAHAN DI SEKOLAH DASAR. Jurnal Karya Pendidikan Matematika. https://doi.org/10.26714/jkpm.5.2.2018.121-125

Kementerian Pendidikan dan Kebudayaan. (2017). Peta Jalan Generasi Emas Indonesia. Kementerian Pendidikan dan Kebudayaan.

Mery Noviyanti. (2011). PENGARUH MOTIVASI DAN KETERAMPILAN BERKOMUNIKASI TERHADAP PRESTASI BELAJAR MAHASISWA PADA TUTORIAL ONLINE BERBASIS PENDEKATAN KONTEKSTUAL PADA MATAKULIAH STATISTIKA PENDIDIKAN. Jurnal Pendidikan. https://doi.org/10.33830/jp.v12i2.494.2011

The 6Cs Squared Version of Education in the 21st Century, (2015).

Nissim, Y., Weissblueth, E., Scott-Webber, L., \& Amar, S. (2016). The Effect of a Stimulating Learning Environment on Pre-Service Teachers' Motivation and 21st Century Skills. Journal of Education and Learning. https://doi.org/10.5539/jel.v5n3p29

Presiden Republik Indonesia. (2005). PP 19 Tahun 2005 Tentang Standar Nasional Pendidikan. Sekretariat Negara RI.

Presiden Republik Indonesia. (2017). Peraturan Presiden nomor 59 tahun 2017 Tentang Pelaksanaan Tujuan Pembangunan Berkelanjutan. In Peraturan Presiden. https:// doi.org/10.1177/0309133309346882

Rahmawati, L. (2020). Pengembangan Model E-Jigsaw Learning pada Perkuliahan Fisika untuke Meningkatkan Keterampilan Abad 21. Disertasi doktor.

Robb, T. A. (2004). Moodle: A virtual learning environment for the rest of us. The Electronic Journal for English as a Second Language.

Sadikin, A., \& Hakim, N. (2019). Pengembangan Media E-Learning Interaktif Dalam Menyongsong Revolusi Industri 4.0 Pada Materi Ekosistem Untuk Siswa SMA. BIODIK. https://doi.org/10.22437/bio.v5i2.7590

Schrum, L., \& Levin, B. B. (2017). Leading 21st Century Schools: Harnessing Technology for Engagement and Achievement. In Leading 21st Century Schools: Harnessing Technology for Engagement and Achievement. https://doi.org/10.4135/9781483395043 
Schuster, K., Plumanns, L., Groß, K., Vossen, R., Richert, A., \& Jeschke, S. (2015). Preparing for Industry 4.0 - Testing Collaborative Virtual Learning Environments with Students and Professional Trainers. International Journal of Advanced Corporate Learning (IJAC). https:// doi.org/10.3991/ijac.v8i4.4911

Slavin, Robert, E. (1995). Cooperative Learning Theory and Practice. Allyman \& Bacon.

Sommer, L. (2015). Industrial revolution - Industry 4.0: Are German manufacturing SMEs the first victims of this revolution? Journal of Industrial Engineering and Management. https://doi.org/10.3926/jiem.1470

Sugiyono. (2017). Pendekatan Kuantitatif, Kualitatif, Kombinasi, R\&D dan Penelitian Evaluasi. In Metodelogi Penelitian. Alfabeta.

Tarhan, L., \& Acar Sesen, B. (2012). Jigsaw cooperative learning: Acid-base theories. Chemistry Education Research and Practice. https://doi.org/10.1039/c2rp90004a

Trowbridge, W. L. \&. Bybee, W. R. (1990). Becoming a secondary school science teacher. Merrill Publishing Company. 